\title{
Conviviality and the Life of Soil
}

\author{
Michael Given
}

Soils provide a striking demonstration of conviviality, thanks to the intensity and abundance of lively interaction seething within them. Soils constitute and generate life precisely through the symbiotic interaction, collaboration and competition of an enormous range of partners. Engaging with some specific soils in central Cyprus demonstrates how this conviviality works. Soil-places are created by very precise combinations of soil players, both non-human and human. Humans can join these partners in helping the soil to grow, through constructions of check dams to catch sediments and moisture. They can use soil to construct houses, demonstrating deep local knowledge and close partnership with the soils, and often recognizing the conviviality that provides a foundation for their lives in the landscape. As our soils today are catastrophically degraded and lost, the need to engage with the conviviality of soil is all the more urgent.

For all its supposedly natural character, the soil in my vegetable bed seems artificial, a mere human construct. It is hemmed in by raised sides for good drainage. I have drastically reduced its biodiversity to potatoes and broad beans, and regularly dig it over to expose its bare surface. It depends on all the artificial nutrients I have added over the years and is full of archaeological detritus from previous generations of builders and gardeners, as well as bits and pieces from my own family, introduced through the vagaries of what goes into our kitchen compost bin.

But is soil really a mere construct of human agency and ingenuity, one more machine in our Anthropocene environment wholly dependent on human manipulation and repair (e.g. Forbes 2013, 555; Hodder 2014, 33; see Whatmore \& Hinchcliffe 2010, 442)? Or is characterizing the environment as anthropogenic just a new manifestation of that anthropocentric outlook which has been our licence to make of the world what we will? Are we just affirming that centuries- or millennia-long act of hubris that is now having such devastating consequences on soils, biodiversity, climate, habitats, sea level and water supply?

The fundamental essence of soil is an astonishing, mind-boggling abundance of life. A gramme of reasonably productive soil can hold up to 200 million bacteria and an equally astonishing diversity of life forms (Ashman \& Puri 2002, 70; Fouke 2011, 148). Bacteria, water and soil particles interact with a plethora of other life forms: nematodes and earthworms; decaying organic matter; trampling ungulates; and plant roots of all shapes, depths and abilities. All these partners have their own particular actions and contributions. Symbiotic relationships between fungal fibres and plant roots can connect fungus and plant colonies across hundreds of metres: these fungal networks can transmit nutrients and chemical messages, not just to their constituent fruiting fungus heads, but to other plant species, giving my broad beans advance warning of aphid attacks, for example (Babikova et al. 2013; Tsing 2012, 142-3). These fungal networks and the inter-species communication and interaction they facilitate are a powerful stimulation for us humans to appreciate the complexity of the vast network of life that constitutes soil. Soil generates life itself through this network of relations; it is a coherent organism of such wide collaborative power that it is a 'crucible of terrestrial life' (Hillel 2008, 1). And that is without any human intervention at all.

The aim of this article is to engage with this crucible of life, with soil and with what soil does, and through that to understand better how humans relate to and depend on it. I will do this by examining some very specific soils in central Cyprus, investigated

Cambridge Archaeological Journal 28:1, 127-143 C 2017 McDonald Institute for Archaeological Research. This is an Open Access article, distributed under the terms of the Creative Commons Attribution licence (http://creativecommons.org/licenses/by/4.0/), which permits unrestricted re-use, distribution, and reproduction in any medium, provided the original work is properly cited.

doi:10.1017/S0959774317000609 Received 13 December 2016; Accepted 2 August 2017; Revised 13 July 2017 
as part of the Troodos Archaeological and Environmental Survey Project (Given et al. 2013a). From an archaeological perspective, this involves pushing archaeological theory beyond its fixation with people and their things (e.g. Hodder 2012; Nativ 2014) and drawing on ideas and analyses from the natural sciences, cultural geography and environmental philosophy. My approach to dealing with this has been to develop the theory and practice of conviviality, following Illich (1975) and Whatmore and Hinchcliffe (2010, 452-3). Conviviality is a framework for understanding the richness of interaction and interdependence of all the human and more-than-human actors that generate the lively world we inhabit and share.

And yet the impact of human contributions to landscape and life across the biosphere is unavoidable, reaching levels that are not so much transformational as catastrophic. One of the worst affected is that crucible of life, soil (Figure 1). Thanks to the techniques practised in miniature in my garden, agricultural soils are eroding between 10 and 100 times more quickly than they would if covered in local, self-perpetuating vegetation (Montgomery 2007). Landowners and consumers across the globe are destroying some 12 million hectares a year through soil degradation, ranging from erosion of soil particles and loss of soil nutrients and organic matter to contamination, salinization and compaction (Rickson et al. 2015).

The human destruction of soils is exacerbated by human-created pollution and climate change. To take Cyprus as an example, the dangers of massive soil loss through unsustainable agriculture and grazing are amplified by the pollution of soil and water through agricultural chemicals, industrial waste, salinization, decline in soil biodiversity, soil sealing, effluent from livestock and urban sewage (Delipetrou et al. 2008, 194-5; Zomeni \& Bruggeman 2013, 53-6). Meanwhile, anthropogenic global warming is making the eastern Mediterranean a climate-change hotspot. Nicosia is warming by $0.33^{\circ}$ a decade (Lelieveld et al. 2012, 677), while by the middle of the twenty-first century precipitation will have dropped by as much as 7 per cent and summer maximum temperature risen by $2^{\circ} \mathrm{C}$ (Hadjinicolaou et al. 2011, 455). This is having a drastic effect on the habitats of all of us, humans and non-humans alike.

So is soil just one more human-built and humanoperated machine in a wholly anthropogenic environment? Or is it a composite organism that generates life through collaboration and competition across aeons of changing contexts and new challenges, including this most recent one? To address this, I will first discuss how the concepts of vitality and conviviality can help us understand and engage with the soil and the environment more widely. This is followed by three case studies which document at different scales the generative properties of soil and the intricate involvement of human communities with it: soil-places in the landscape; soil generation in check dams; and the participation of soil in mud-brick houses.

\section{Approaching soil}

From the perspective of the soil sciences, the prominent role of soils in supporting human life is unquestioned. By orchestrating the interactions of a host of minerals, nutrients, organic matter, water and gases, it acts as a bank to store and deliver what plants and, indirectly, animals such as ourselves need to grow (Hillel 2008, 2). With microbe and soil fauna partners, soils break down dead plant and animal material and act as living filters to remove toxins and disease (Hillel 2008, 2,5). This definition of the constituents and role of soils has proved challenging to share with a wider public, however. Soil and its legions of microbes and soil fauna are unprepossessing, out of sight and out of mind beneath our feet; they lack the cuteness value of environmentalist icons such as pandas or polar bears. In modern Western society it is hard to convince people of the moral imperative of respecting our soil (Fouke 2011, 152-3).

There is an important role here for arts and humanities researchers, integrating cultural perspectives with the scientific and looking back at the relations of societies in the past with their soil. Archaeologists, historians and anthropologists have done just this by investigating societies that give soil a prominent role in their systems of values. Though the case studies and insights of this body of work are very stimulating, much of the writing remains descriptive and undertheorized (Salisbury 2012a, 23-4), and often anthropocentric. My own approach works through from the agency of living beings and environmental processes to vitality and conviviality.

\section{Soils have agency}

It is perhaps natural that in demonstrations of agency archaeologists have focused on humans, their things and the materials that their things are made of. But what about other living beings-Ingold's 'missing nonhumans' $(2012,429)$ ? And what about other environmental processes and potential agents: can rain, wind and soil have agency? Plants such as sugar cane and coffee directly impact the physical health and emotional well-being of the humans who consume them, as well as enslaving other humans for their care and production; both of these sets of actions very 


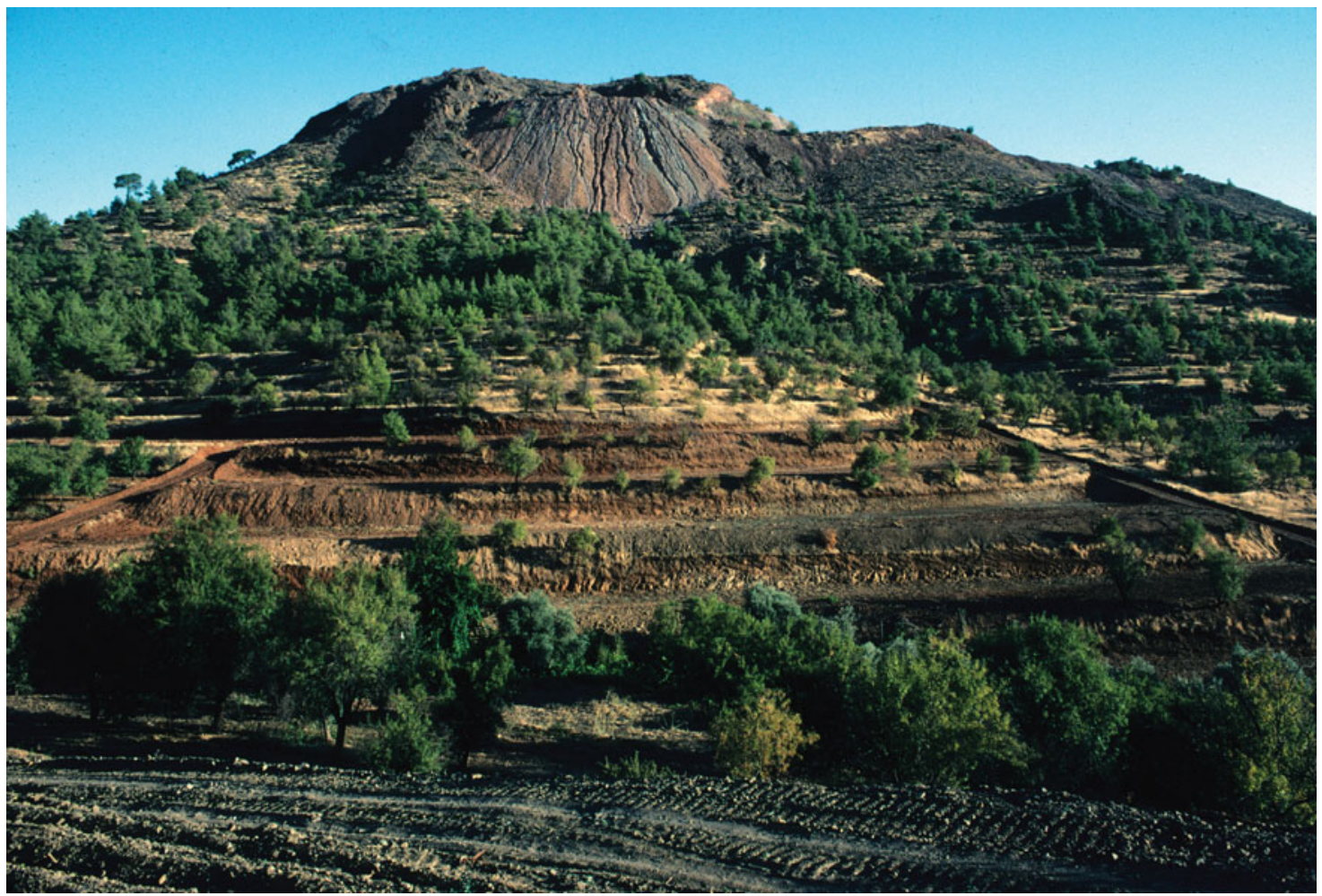

Figure 1. Alestos, Cyprus, showing (from top) spoil from twentieth-century copper mine, built terraces, bulldozed terraces and bulldozer tracks, July 2003. (Photograph: Chris Parks.)

clearly demonstrate agency (van der Veen 2014, 8069). Water brings its unique fluidity, its ability to transform to ice and steam, to connect and to hydrate living things (Strang 2014, 133-4). Wood, far from being a 'raw' material once cut off from the tree, still resists or aligns with the gestures of carpenter or basket-maker; sometimes, as with willow, it even continues to grow (Bunn 2014).

The symmetrical archaeology programme urges the inclusion of all living beings and environmental processes into the realm of agencies that connect the human and non-human world (Olsen 2012, 212). In spite of this, the emphasis is very clearly on, once again, humans and their things. There is a striking asymmetry in Olsen's actual exclusion of animals, plants, soils and other environmental agents from his analysis and case studies (Olsen 2012; see Ingold 2012, 431; Salisbury 2012a, 23). Similarly, Witmore's $(2014,206)$ presentation of 'new materialisms' eagerly counts air, soil, rain, sea and bacteria as 'things', and is careful not to give humans any ontological privileges over other things $(2014,215)$. But again, there is little engagement with the physical realities and properties of the 'microbes, hedgehogs, water, compaction, etc.' that transform a former house in a one-sentence, rather generic example (Witmore 2014, 215). Just as archaeologists need to rematerialize material culture (Ingold 2007), so do we need to re-engage with real soil, to feel it ooze between our fingers and toes, to follow it as it participates in the ongoing generation of life.

But what can soil-or anything else-do on its own? How can it ooze between fingers and toes if it does not work with water and clay particles? And what is soil without bacteria, soil organic matter, arthropods, rain, carbon, rock particles, air spaces? For all the intrinsic properties of a hammer or a boulder, on their own they are dead. They need a swinging human arm or a steep slope to energize them so they can act in the world. Their agency is hybrid, deriving from their work together in a collective (McMaster \& Wastell 2005). Individual agency, whether of living being, artefact, material, or soil, cannot explain the lively action and interaction of the world.

\section{Soils are alive}

Look at a field, says Daniel Hillel, and all seems quiet and calm; a romantic poet would see it as a place of 'idyllic serenity'. The environmental scientist, however (and I would add the environmental 


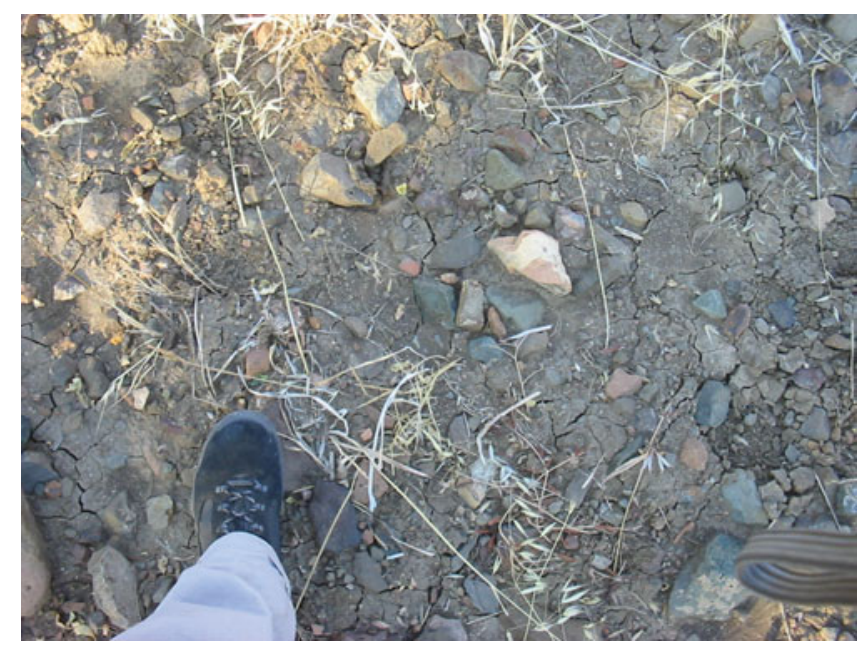

Figure 2. Surface of Survey Unit 2605 in July 2003: Quaternary gravelly colluvium, Roman self-slipped amphora toe, soil colour of 5 Y 6/3, oats, cracks from drying, basalt chunks, team leader's boot, red body sherds. (Photograph: Angus Graham.)

philosopher: Fouke 2011, 148), sees 'a seething foundry in which matter and energy are in constant flux' (Hillel 2008, 1; Fig. 2). All of soil's properties, agency and power come not from an essential monolithic substance, but from the myriad partners that constitute it.

It is not just soils that have this property of vibrant, heterogeneous vitality. For Jane Bennett, electricity grids, rubbish dumps and other 'vibrant matter' have exactly this capacity to conglomerate, to form powerful assemblages of heterogeneous nonhumans and (sometimes) humans; it is the assemblage, not the individual, that develops its trajectory and acts in the world (Bennett 2010, xv-xviii; see also Crellin 2017, 113-15; Hamilakis 2017, 172). Along with soils, ant colonies and whole ecosystems, they are alive in a more-than-physiological sense, irreducible to human constructions, sets of properties or networks of interaction.

And we are alive in the same sense, in spite of the continuing sway that the myth of the selfcontained individual' holds over our minds (Fouke 2011, 153). The parallels with soil are striking: like soil, we depend on huge colonies of microbes in our bodies, whose numbers far outstrip the numbers of our own cells. Fortunately for us, they have evolved abilities such as extracting nutrients from food and using oxygen to generate energy, which we cannot do on our own. Added to that our often intimate relationship with clothes, tools and built structures, living in such extended collectives gives us an infinitely wider repertoire of action and affordance (McMaster \& Wastell 2005, 178). Far from being individu- als, we are, like soils and all living beings, communities living in symbiosis: 'we are ecosystems' (Fouke 2011, 153-60). Like soils, the boundaries between our 'selves' and our environments are semi-permeable, as we exchange energy, nutrition, physical support and thought with our equally semi-permeable partners (Barrett 2014, 71-2; Ingold 2012, 438). Symbiosis is what generates life.

\section{Soils are convivial}

A common problem in much archaeological theory is its retreat into abstractions, its refusal to do precisely what archaeology does best: getting to grips with the things, the materiality, the soil, the world (Ingold 2007; Knappett 2012, 201-2). We need an approach that integrates a stimulating theoretical framework with a specific 'ecology of practices' that allows us to immerse ourselves in the world we have externalized through research and analysis (Pétursdóttir 2012, 578). Given the challenges of soil erosion, pollution and climate change that our world faces, this approach needs to engender a political project as much as a research project (Bennett 2010, viii).

For me, the term for that theoretical approach, ecology of practices and political project is 'conviviality'. Etymologically, it suggests a 'living together', precisely that vitality through symbiosis that I have just discussed, most vividly and powerfully enacted in the ongoing life of soil. The philosophical use of the term was initiated by Ivan Illich $(1975,24)$, to refer to 'autonomous and creative intercourse among persons, and the intercourse of persons with their environment', where 'intercourse' refers to intense 


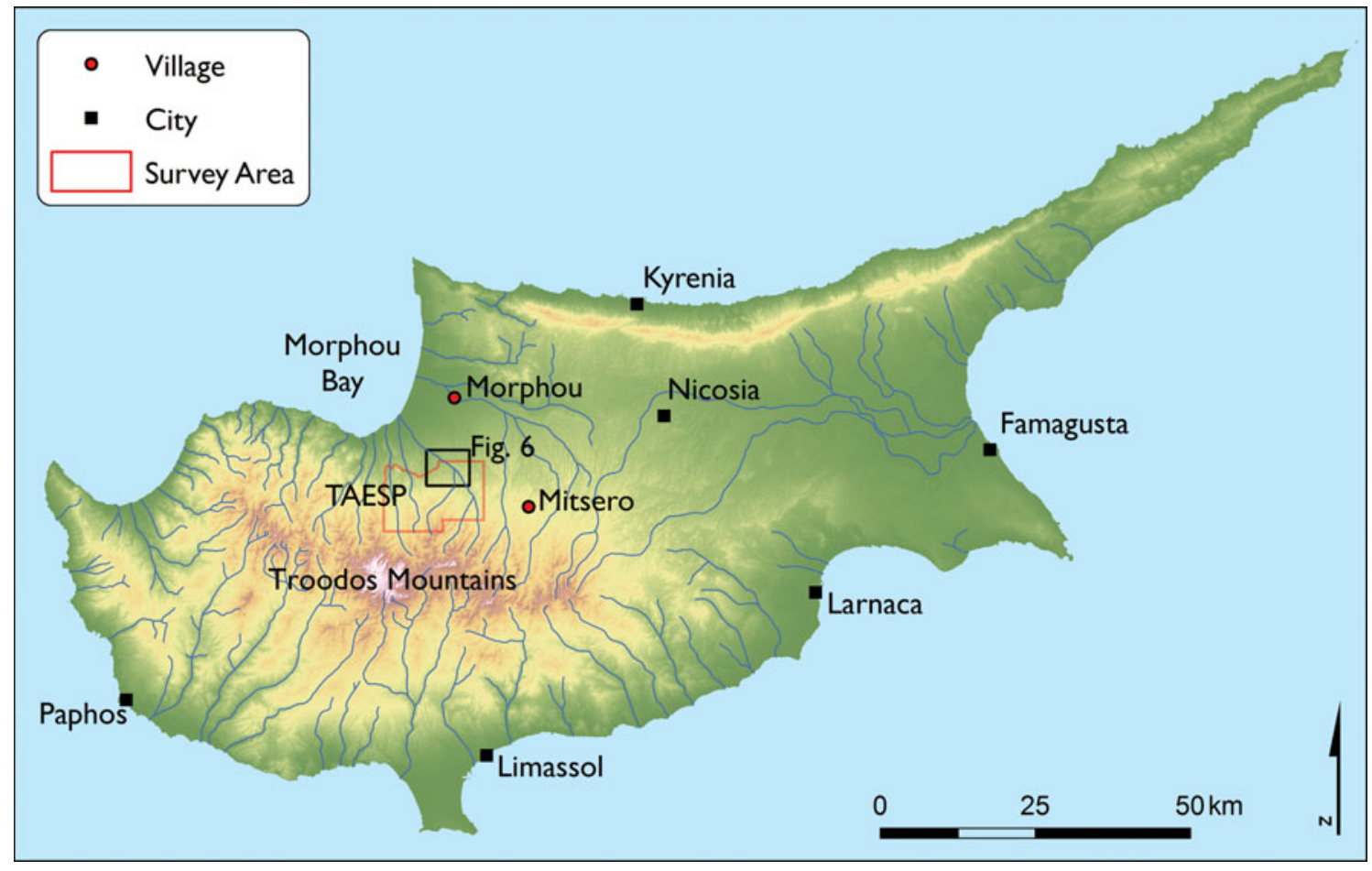

Figure 3. Cyprus. (Map: Michael Given.)

and wide-ranging interaction and engagement. Importantly, this was constrained only by the need to preserve everyone else's own autonomy and creative freedom (Illich 1975, 25-6). As a theoretical approach for today, it celebrates the shifting, emerging, fading, struggling connections and interdependencies that in their unfathomable complexity constitute life. It stresses that strivings such as growth, politics, community and livelihood are 'co-fabrications' between a host of co-dependents with their own needs and limits, non-humans and humans alike (Whatmore \& Hinchcliffe 2010, 453).

Partly because of the contemporary jovial connotations of the term, it is easy to fall into an idealist or romantic sense of conviviality as some sort of vaguely defined 'harmony' between people and the environment (e.g. Bassey 2012; see Illich 1975, 13-14). Competition, tension and conflict are as much part of convivial relations as symbiosis and collaboration. And we cannot assign human value judgements to these relationships. When a goat eats a cyclamen flower, it is irrelevant that this is 'good' for the goat and 'bad' for the flower: what matters is the continuance of the cycles of matter, nutrients and life. A goat eating a flower and returning its nutrients to the soil by defecation and decay maintains the conviviality; it works within the limits of the symbiosis. Spreading tarmac and concrete over once lively soil does not.
As has already become evident, the term conviviality as I use it owes much to assemblage theory and actor-network theory. It acknowledges the agency and centrality of assemblages of a wide range of players (or actants) such as soils, animals (including humans), plants, materials, artefacts, environmental processes and human technologies and memories (Hamilakis \& Jones 2017, 81). Heterogeneity is an inevitable but central consequence of this all-encompassing diversity, as is the participation of local histories of action, collaboration and tension (Hamilakis 2017, 173-4). Similarly, conviviality enthusiastically supports the Latourian philippic against human/non-human dualism (McMaster \& Wastell 2005, 176-7) and shares a determination to transgress 'the boundaries that cordon nature from culture' (Tsing 2012, 141).

What conviviality brings to this, other than a certain expressive power driven by the popular connotations of the term, is a commitment to the central role of non-human and non human-made players. In this sense it moves on from Illich's own main interests in the establishment of a just society based on individual human freedom, autonomy and responsibility. In another way, however, it brings precisely this practical, future-oriented and ethical approach to our engagement with the landscape. Conviviality is a physical practice, a deep and sensory engagement with the landscape and the world (Hamilakis 2017, 172-3; 


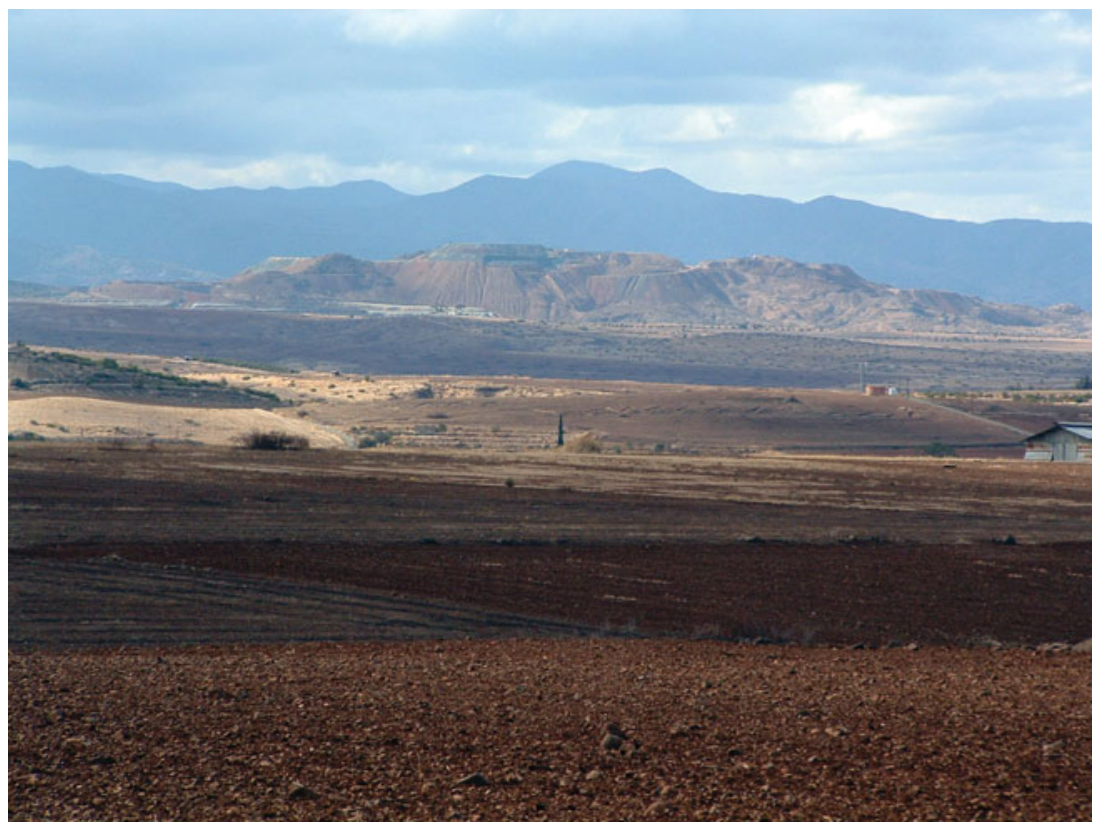

Figure 4. Looking west across the Koutraphas pediment to Skouriotissa copper mine and the western Troodos Mountains, November 2003. Foreground shows terra rossa (2.5YR 4/3) containing haematite clasts, pottery and lithics. (Photograph: Hugh Corley.)

Tsing 2010, 201; Wylie 2007, 166-7). Like animism, it offers a 'respectful and attentive awareness' of the non-humans we share the world with, and on whose symbiosis we depend (Jones \& Boivin 2010, 343).

Conviviality is also a rhetorical practice, a channel of communication: it uses active verbs, stories, word painting and art, in the field, in public and in the text. As a political project, it requires the subverting of favourite myths and habits and, as we shall now see, the generation of new, convivial geomythologies.

\section{Soil-places}

Once upon a time, deep in the Middle Pleistocene, there was a river. And the river carved its way through the upturned layers of the ophiolite: the dense, speckled gabbro; the hard, microcrystalline sheeted dykes of the basalt, interleaved with massive flows of lava that spurted out onto the sea bed back in the Upper Cretaceous; and then, as it passed on down the ophiolite dome, it cut into the hard Lower Pillow Lavas and softer Upper Pillow Lavas. In its calmer phases, the river scoured off sand and silt from these different donors, and in flash floods drove off cobbles and boulders and piled them up high in great fans at the base of the range.

As the Middle Pleistocene went on, the African plate thrust its way under the ophiolite, heaving it up even further, forming what we now call the Troodos Mountains of Cyprus (Fig. 3). These new elevations gave power to new rivers which cut down through fresh ophiolite. The fans on the north side of the range began to coalesce, generating a sweeping, undulating piedmont running down to an ancestral Morphou Bay. Later rivers filled old valleys and their successors incised them again, leaving high, level pediments of old alluvium upstanding (Main et al. 2016; Noller \& Urwin 2013, 298-9, 305; Zomeni \& Bruggeman 2013, 41).

And it was here on the surfaces of the old pediments that the soil partners began their convivial work. Colonizing lichens and bacteria worked with the silt and rock particles to create matrix and nutrients, which could then host the bacteria, plants and microfauna that joined in the collaboration and developed the first soil. This soil matured, deepened and changed as carbonates and other minerals were leached through it. It aged and weathered and oxidized, becoming the deep iron oxide red of terra rossa (Fig. 4). Together, all these partners worked to capture and hold the rainfall, and with it they nurtured grasses, steppe-shrubs, conifers (probably pines) and wild cereals (Given et al. 2013b, 9).

All this is pure place-making. The archaeological literature on soils discusses soil-places only in terms of what humans have done to it. People have worked and altered the soils, making 'cultural soilscapes' 
(Salisbury 2012b, 178-9; Wells 2006); they have intervened using fertilizers, creating plaggen or Dark Soils (e.g. Blume \& Leinweber 2004); they have made soil meaningful to themselves by recognizing local colours, types and textures (Evans 2003, 70). But even before humans arrived in Cyprus, place-making by the soil was elaborate and finely resolved, an ongoing project that was part of its convivial being. Because of the complexity of its geology and climate, Cyprus is characterized, not just by its microclimates (Delipetrou et al. 2008, 174-5), but by its exceptional diversity of soils and, therefore, its soil-places (Zomeni \& Bruggeman 2013, 38).

There is an epilogue to this soil story. In chronological terms, it is vanishingly minor; in its impact on the soils, it is significant; and to us humans, it is of particular interest. Right at the end of the Pleistocene, or the beginning of the Holocene, humans joined in the conviviality. They too collaborated with the soil, rocks, plants and animals. The first ones on the Koutraphas pediment (Fig. 6) found red jasper nodules and diabase river boulders and made them into ad hoc tools to harvest and grind the wild grasses, leaving them behind to become players in the soil in their own right (Given et al. 2013b, 40-41). In the Bronze Age, humans engaged with the soil and its partners more elaborately and systematically, by selecting and tending soils, waters and grains. Or, to put it less anthropocentrically, the soils and grains selected and tended these new, useful partners who delivered more dedicated environments and evolutionary advantages (van der Veen 2014, 801). The humans delivered stone tools, debris, grinding stones and now pottery to the matrix of these old soils and Pleistocene surfaces (Given et al. 2013b, 41-3).

By the Roman period, human engagement with the soil had spread well beyond individual 'sites'. Over in the broad, well-watered Karkotis Valley, 10 $\mathrm{km}$ to the west, artificial land levelling and irrigation to grow the crops for supporting the massive coppermining operation at Skouriotissa moved something in the order of 1-3 million cubic metres of sediment (Boutin et al. 2013, 101-2). Here on the plains, with their fertile soils but barely adequate rainfall, even in the climate optimum of 100 BC-AD 200 (McCormick et al. 2012, 174), Roman use of the soil is systematic but relatively dispersed. Its long-term impact consists of broad spreads of pottery from intensive cultivation and manuring, and small, perhaps seasonal, farming hamlets long since ploughed out, their pottery and mud brick architecture all returned to the soil (Given et al. 2013b, 43-5).

Medieval estates continued the irrigation and land sculpting of the Roman period, if at a rather smaller scale. The early sixteenth-century estate at Kato Koutraphas, for example, divided its 237 ha of brown Holocene alluvium, rust-red Pleistocene pediment and the steep scarp between the two into irrigated, dry, cropped, fallow and uncultivable land. Light scatters of Medieval pottery, particularly storage wares, in the terra rossa of the adjoining part of the pediment mark out the estate's outlying farmsteads (Given et al. 2013b, 46-7).

The chief protagonist of this million-year history is clearly the soil. Medieval estates, early Neolithic gathering sites and Roman farmsteads are built by soil micro-organisms, rainfall, particles of igneous rock brought down by successive rivers from the ophiolite, processes of weathering and leaching, and brokendown plant material. The sherds in the ploughsoil and stubs of mud-brick houses mark generations of material participation in that convivial place making, not a unilateral human construction of the landscape.

Because of limits to human vision and perception, outside analytical spaces such as this article, people's material engagement with the conviviality of soil has to target what is perceptible as they engage in their various soil tasks: texture, colour, smell, stones, larger pieces of vegetable matter and, as we have seen, the remains of human artefacts. This is certainly my experience as gardener/archaeologist. I recognize and welcome the little pieces of me, my family and our predecessors that have become part of the soil: scraps of 'compostable' vegetable bags that haven't quite composted; stamped bricks from brickworks whose production spans the twentieth century; eggshells and sprouting avocado stones from the kitchen compost; and, to my astonishment, a sherd of what had once been my favourite mug. As another gardener/archaeologist points out, these are all part of culturally specific 'waste streams' (Forbes 2013, 559-61). The conviviality lies in the interlocking of waste streams with soil-nutrient cycles.

On a broader scale, the human incorporation of matter into the soil takes place most commonly through manuring. What is now a considerable literature relates wide but low-density scatters of pottery with past manuring practices. Even if heavy or sharp fragments of broken pottery are disposed of elsewhere, smaller sherds end up in the domestic manure heap along with kitchen refuse and sweepings, and so are spread evenly across the fields (Forbes 2013). This provides a soil signature that is not just visible to archaeologists. These sherds and other recognizable fragments texture and identify the soil-places of particular owners or social groups. In English 
medieval estates, for example, seigneurial manure heaps were placed at a distance where the lord could not smell them, so tended not to contain domestic debris, as opposed to the peasants' manure heaps outside their doors. These material differences were physically transferred to the fields, where they engendered social tension and spatial negotiation on the arable soils (Jones 2009; see also Evans 2003, 125; Given 2004).

Talking to farmers while doing survey in Cyprus, we were told about sherds coming from the manure. One woman used to play with the 'coloured half-cups' (medieval sgraffito) as a girl while her father ploughed; another could recognize her own family's broken table-ware in her field. Mandres is characteristic of a settlement dating from the medieval to the early twentieth century, with a halo of lowdensity pottery marking its manured infields stretching around it for $200 \mathrm{~m}$ or so (Fig. 5; Given et al. 2013b, 38; cf. Given 2004; Wilkinson 2003, 117-20). Even within this, there is a variety of soil-places: that on the eastern edge of the village has high proportions of Roman pottery, easily distinguishable to the curious (see also Jones 2009, 221-2); worn, cast-off threshing-sledge blades can be identified round the threshing floors; and increasing sherd density marks your progress towards the settlement.

Language plays an important role in this human filtering of conviviality. Through place names, it enables a density and precision of local knowledge and practices to be transferred to others across distances of space and time. This is celebrated in the place-glossaries of Macfarlane's Landmarks (2015), where terms like the Northamptonshire 'maumble' ('the moist soil that clings to the spade in digging') $(2015,203)$ convey the 'slow capillary creep of knowledge, up out of landscape's details and into language's' $(2015,25)$.

The Greek Cypriot version of Macfarlane's glossaries has a list of 170 locality names that specifically refer to soil quality and fertility (Panaretos 1967, 99106). The precision and particularism of these terms are just as striking as Macfarlane's: koutsopetrin, 'full of little stones, usually beside a river or over ruined buildings' (Panaretos 1967, 101); pourkourokhoma, 'crumbly soil with no cohesiveness, like pourkouri [cracked wheat]' $(1967,104) ;$ kafkalla, 'stony soil, with little or no depth' $(1967,100)$; mavroin, 'black soil, fertile and productive' $(1967,100)$. Around Koutraphas and Mandres, the locality names have a spatial as well as semantic precision, growing out of the conviviality between soils, practices, things, language, environmental processes and living beings (Fig. 6). These names show a sharp eye for colour and for useful ma- terials such as lime, reeds and konnos, a white clay used for roofing. They record how people have engaged with the soil through manuring an infield, irrigating, trying to plough a stony field, or walking to the outfield.

Soil-places are neither environmental constants nor human constructions. Whatever the blinkered view of the humans, or any of the other players, they grow out of the conviviality of the soil.

\section{Soil generation}

In the beginning there was rock, and the rock emerged from the waters, and it folded and weathered and cracked. And so it could welcome the first bacteria, which fixed atmospheric nitrogen so that other bacteria, fungi and lichen could multiply and in turn support more plants and microfauna. Clay recrystallized from the disintegration of rock particles and worked with the humus, the plant material that could resist being broken down. And gradually these partners developed their shared and complementary physical and chemical abilities, giving them the power to hold and release water and nutrients. With that, they had become soil (Ashman \& Puri 2002, 2-17).

Thanks to the convivial work of its collaborators, soil generates itself. If all matter is generative through its distributed liveliness (Whatmore \& Hinchcliffe 2010, 448), then soil is doubly so, as it focuses on the project of its own ongoing growth and development (Barrett 2014, 71). There are so many collaborators in this stupendous demonstration of mass conviviality that it needs a litany just to begin conveying its breadth and intensity: earthworms, and the air tunnels they create; the rainwater which can infiltrate through the air tunnels (Pimentel 2006, 129); soil organic matter; the trampling hoofs and phosphorusrich dung of cattle, and sometimes their decaying bodies as well; the chemical memories of past crops and weeds (Salisbury 2012b, 181); the ploughshares and spades that break down soil structure; the scouring of rivers and slope-generated sheet erosion; human knowledge and participation.

Like plants (van der Veen 2014, 801), soils recruit all sorts of players to help maintain their nutrient cycles. These include, of course, humans, like me in ' $m y^{\prime}$ vegetable bed, working to serve the needs of the soil along with the humus, the billions of bacteria and the knobbly white nitrogen nodules in the roots of the broad beans. People can be humble, in the word's etymological sense of being humilis, close to the humus or soil. They can join in the conviviality and be one contributor among billions, particularly when they are prepared to work within convivial limits and on the 


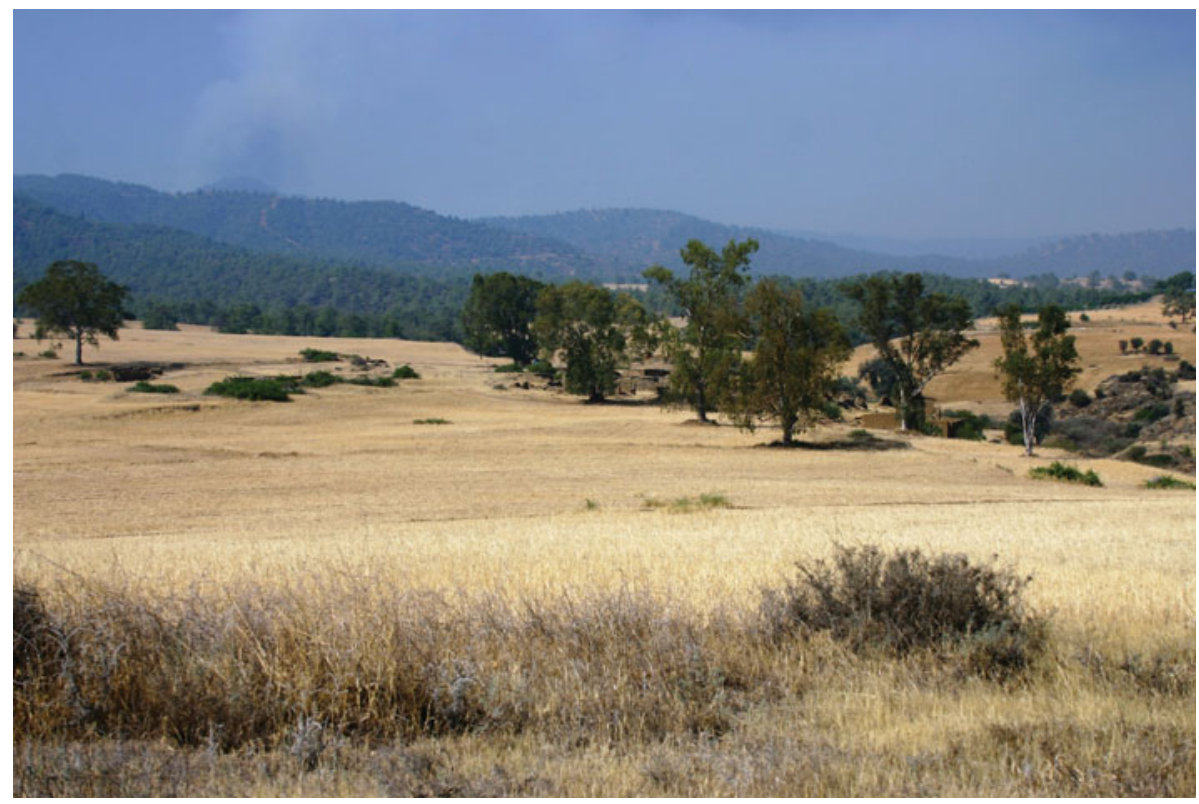

Figure 5. Mandres from the northeast, June 2016: mud-brick buildings behind the cluster of eucalypts, which mark threshing floors; Pleistocene terraces incised by gully; Troodos range with forest fire. Field in foreground: Quaternary alluvium, mainly silt; gravelly; 10YR 5/4. The fields between the foreground and the settlement have a 'manuring density' of 1-4 Medieval-Modern sherds per 10 sq. m, rising to 5-13 on the immediate outskirts of the settlement. (Photograph: Michael Given.)

soil's time scale. So people cannot 'make' soil, but they can help it grow (Ingold \& Hallam 2014).

Or, alternatively, people can try and deny the conviviality of the soil and their own dependence on it. If they ignore the limits to convivial life and see the soil as a given, always there, a fixed part of the environment, it is all too easy to exhaust or degenerate it, treating it as an uncosted externality in the books of supply and demand: hence the millennia of accelerating erosion, nutrient-stripping and shattering of soil structure.

Manure is one obvious solution to human demands for a more intensive agriculture, in which livestock join the convivial partnership of the soil. But there is another important partner that has worked hard over the millennia to bring back to the soil the nutrients that humans have extracted: running water. In the form of the annual floods of the Nile, this has generated Egyptian soils, agriculture and human society from the predynastic period to the construction of the Aswan High Dam in 1963. In the semiarid lands bordering the deserts of the Middle East and north Africa, great walls were built across wadis to store the water and sediment brought down by flash floods, creating huge systems of irrigated agriculture and new, deep soils, particularly during the Roman and early Byzantine empires (e.g. Ashkenazi et al. 2012; Vita-Finzi 1969, 12-26; Wilkinson 2003, 192-5).

But the apogee of this human collaboration with soil and running water at the microscale was the humble check dam. There is a characteristic one on the Pleistocene pediment east of Koutraphas, at a locality named Strata Oritissas (Fig. 7; see Fig. 6 for a map). A minor tributary of the Xeropotamos, the evocatively named 'Dry River' which today fails to reach Morphou Bay, has incised the beginnings of a shallow gully into the old Pleistocene surface. The deimma or check dam is $c .7 \mathrm{~m}$ long and $0.5 \mathrm{~m}$ high, built of some four courses of rounded river stones brought down by Pleistocene floods. By crossing the gully, it has trapped a load of sediment behind it; its power is all the more evident from a collapsed section at the east end (to the left in Fig. 7), which has allowed a new gully to start eroding.

In Greek, these deimmata [check dams] are carefully distinguished from domes [hillslope terraces]. They trap not just sediment, but moisture; this then promotes microbial activity and the accumulation of humus, which normally decomposes quickly in such an arid environment (Christodoulou 1959, 43). This in turn promotes soil formation, fertility and an improved capacity for holding moisture (Wilkinson 


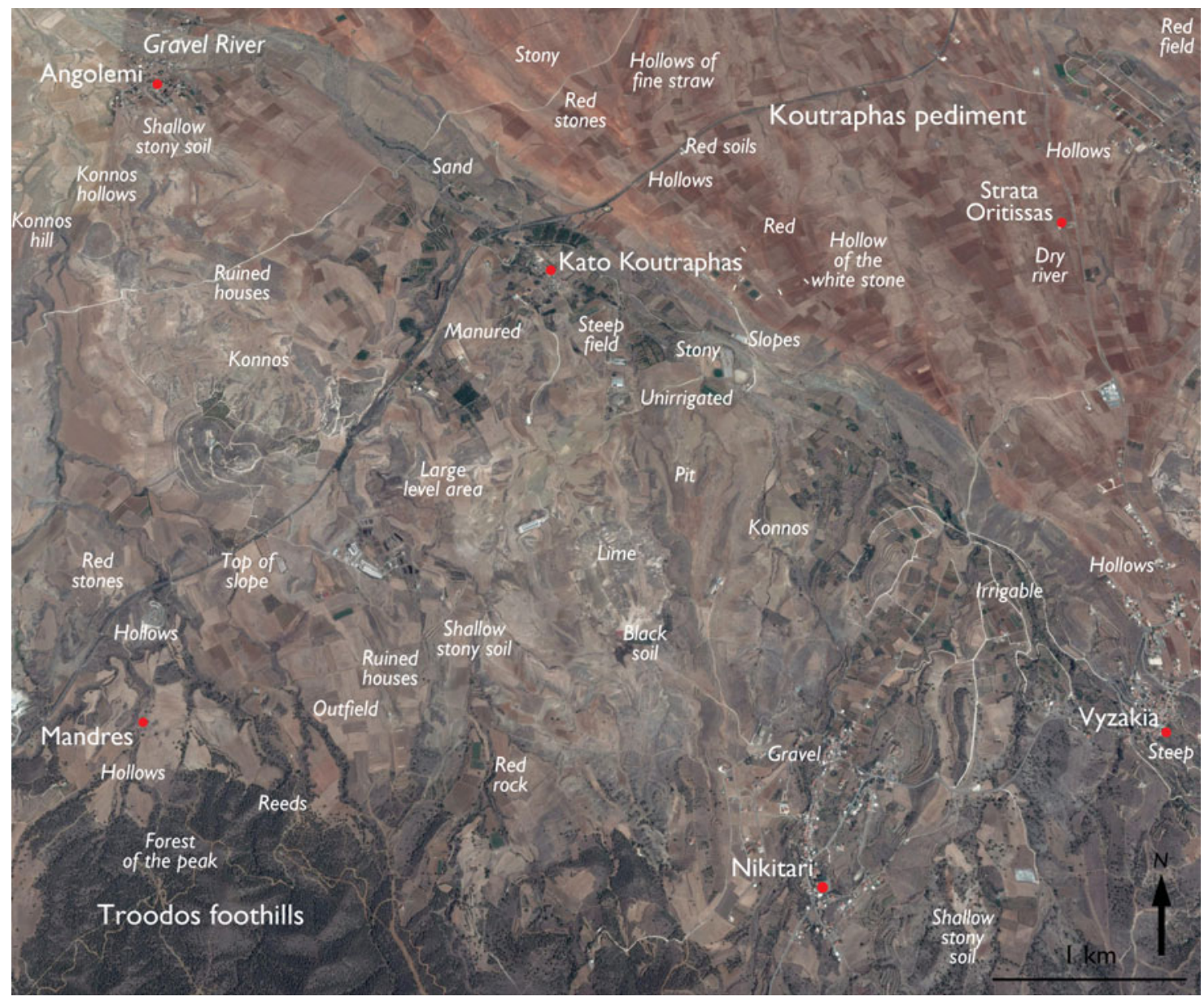

Figure 6. Koutraphas and Mandres area, showing villages and sites mentioned in the text (red dots) and soil-related locality names, based on the 1:5000 cadastral maps. Konnos = white clay for roofing. Translations by the author, with the help of Panaretos (1967, 99-106) and Yiangoullis (1992). (Satellite image: Google Earth, 2016; Map: Michael Given.)

2003, 193). They can be so successful that the sediment completely buries them, making them invisible on the surface and so hard to identify (Noller \& Urwin 2013, 308).

Most visible check dams in Cyprus today, including Strata Oritissas, are likely to date from the Ottoman period to the early twentieth century, at least in their most recent form. Their history goes back further than that, though, as a particularly striking series of large and small check dams scaling the Argaki Kokkinobamboulas ['stream of the red rounded hill'] near the village of Mitsero shows (Given et al. 2003, 190-91). Radiocarbon dating from an exposed section where a large check dam had collapsed shows an ongoing sequence of construction, heightening and repair from $c$. AD 800 to the nineteenth century. In each generation, a thin A horizon of arable soil formed on the surface and then the wall was heightened, which dammed the sediment a little further upstream each time and so increased the soil depth and arable area.

Farmers clearly appreciated the functional benefits of check dams, demonstrated for example in the Greek Cypriot proverb, 'The foolish man manured, while the wise man built check dams' (Panaretos 1967,80$)$. But there are times when people have gone further than that and recognized the conviviality that powers these soil partnerships. The Argaki Kokkinobamboulas derives from a spring opened by a series of landslides back in the Pleistocene (Given et al. 2003,189 ). Since at least the early twelfth century, this spring has been marked and celebrated by a church built immediately over it, dedicated to Panayia Lambadhiotissa, Our Lady of Lambadou, the name of the hill on whose eastern slope the church, spring and stream lie. The built, tunnel-like shrine from which the spring emerges cannot be dated back beyond a century or so, but the association is likely to go 


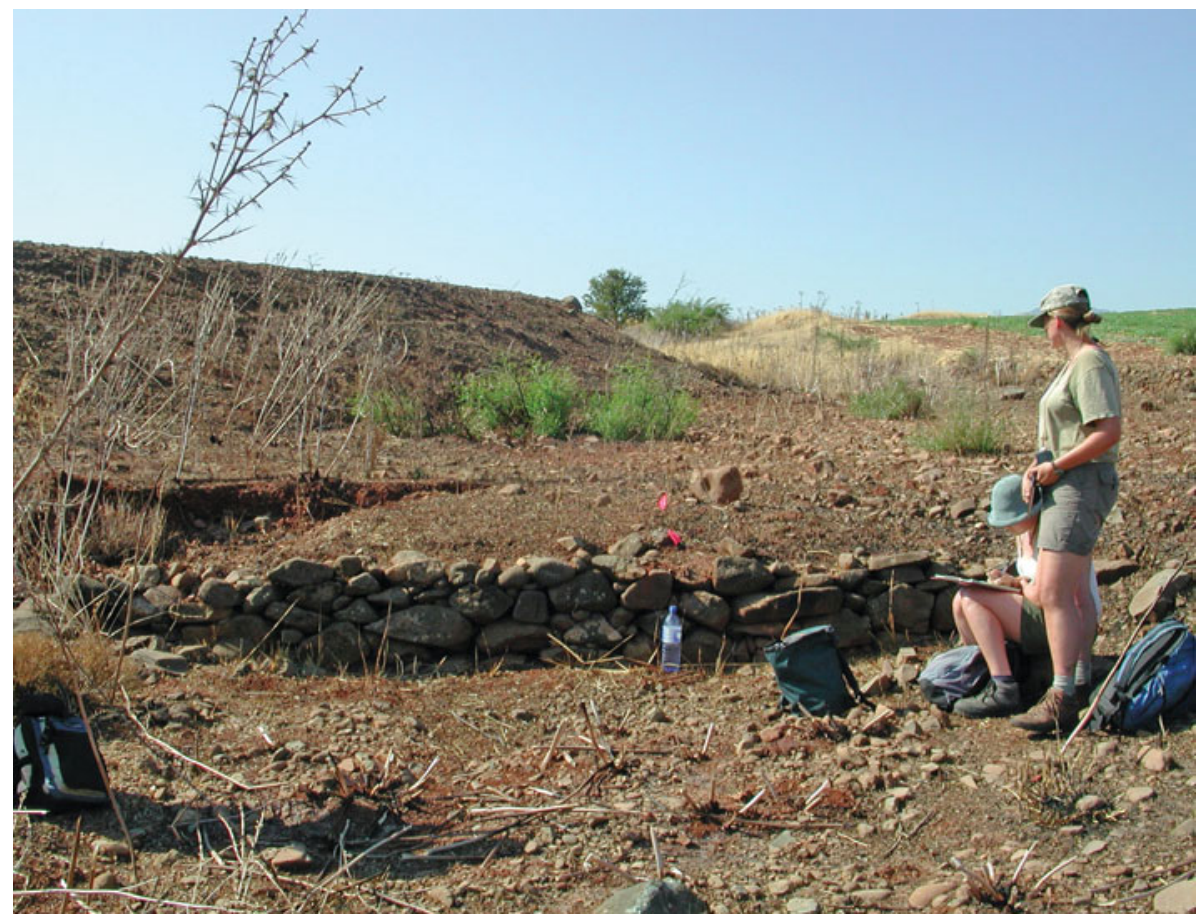

Figure 7. Check dam at Potami Strata Oritissas, trapping cobbly sediment in a shallow gully incised through Pleistocene pediment, July 2003. Soil colour 5YR 3/4. (Photograph: Jackaline Robertson.)

back to the original date of the church, and today there is an icon of the Zoodhokhos Piyi, the Life-Giving Spring, showing water flowing out of a chalice holding Christ and the Virgin Mary. The spring feeds a cluster of tiny fields in the bottom of the bowl created by the landslide and then goes on to generate the soils, waters and agricultural produce of the stairway of check dams running down to the river at the base of the hill.

A farmer we talked to told us that he had built a check dam when his daughter was born, so that by the time she was old enough to be married, it would be full of sediment and a functioning field, to be given away as her dowry. Hamish Forbes demonstrates for the Methana peninsula in Greece how kinship relations are expressed on the ground, in the field boundaries, in the excessively monumental hillslope terraces (Forbes 2007, 318-27). The same is happening here: but it is the soil which generates the conviviality, and humans selectively bind it into their life, nourishment and family.

\section{Building soil}

Listen: for the mud bricks, there were pieces of wood, a square piece of wood, shall we say, cut in half, it was 18 inches long and 9 inches wide. Understand? And $2 \frac{1}{2}-3$ inches thick. You poured the clay in, with the wheelbarrow-before them we had the tsivera [a barrow that slid on a board]. You poured the mud in and straightened it. The mud was kneaded with straw, on its own it's no good, you mix it with straw. My house here is built with mud bricks. . . . We had other fields, out [of the village] and we cut them in our field and stacked them there to dry. And when we started building we carried them with horses, on planks, brought them here and built. It was hard work, very tiring. (Mr Petros [a pseudonym], Tembria village, 17 July 2002)

On the northern edge of the main agglomeration of houses at Mandres there is a free-standing, twostorey house built out of mud bricks (Fig. 8). It rests on a stone socle constructed of limestone chunks and basalt river boulders, with pebbles, fragments of basalt, red jasper and potsherds filling the gaps between them and making the face strikingly variegated. On this is built the wall of mud bricks, thickly tempered with straw, pebbles, pottery and, in one case, bone. There are two storeys, both of which have doors in the southwestern wall whose interior is shown in Figure 8. Above the lower door, a row of slots holds the remains of floor beams, and above that the upper door led to an outside balcony. The interior face of the upper storey has been finished with mud plaster; with age and drying the original handfuls 


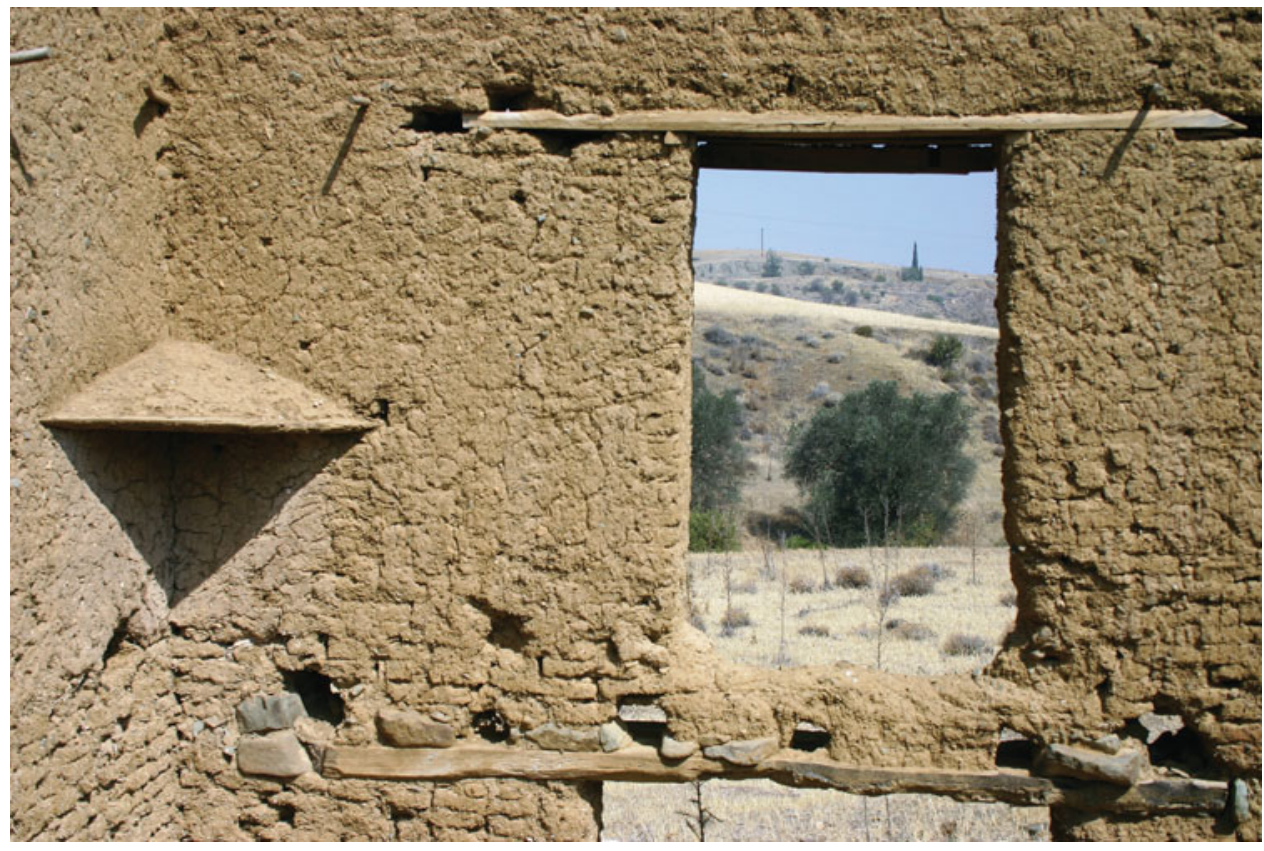

Figure 8. Mandres: interior of house looking northwest, with shelf made of threshing sledge plank (left), upper floor doorway, sockets for beams, mud bricks (below) and mud plaster (above), June 2016. (Photograph: Michael Given.)

have separated slightly and become visible. In the west corner an old threshing sledge has been built in as a shelf, the original chipped stone blades still visible in its under surface; a triangular mound of melted mud brick and plaster covers its upper surface (Fig. 8, left). Looking northwest through the doorway, the old Pleistocene surfaces can be seen, heavily incised by streams coming off the Troodos Mountains immediately to the south (Given et al. 2013b, 26-7).

The inclusions in mud bricks, mortar and plaster are clearly crucial; 'on its own it's no good'. The straw was the thicker portion left from the threshing floors that ring the village, too coarse for the animals to eat. Characteristically, there is a word, ashiropilos, for precisely this mixture of straw and earth used as mortar when laying the bricks (Ionas 2001, 332). Pebbles, sherds and stones show the origins of the mud brick in worked soil from around the settlement. Phosphorus levels in these mud bricks are significantly higher than the general background level, suggesting soil that has been enriched with animal manure or human faeces. People are clearly aware of the long histories of these different components of their houses. As well as the reused threshing sledge and several prehistoric quernstones incorporated into the wall faces of these houses, the sherds in the mud plaster have been placed carefully in the surface to be clearly visible (Given et al. 2013b, 33-4). There is no attempt at pu- rity or consistency; these walls and houses welcome and celebrate the conviviality.

Thanks to a series of interviews with local people, particularly Mr Petros quoted above, we were able to put together a composite account of how mud bricks were made (Ireland et al. 2013, 263-4; see also Ionas 1988, 141-3; 2001, 331-3). The process generally took three days, usually in May and June. On the first day, the soil and water were mixed together; it was important not to sieve the soil first, to leave the inclusions in for binding the mud bricks. On the second day, the mixture was mixed with a spade, trodden with bare feet, pressed into wooden moulds and left in the sun to dry. On the third day, the bricks were taken out of the mould and propped up in pairs so that the air could circulate on both sides and dry them. The impact of this on the landscape was substantial. One of our informants remembered a neighbour who bought a field that was $2 \mathrm{~m}$ higher than the adjacent road, and after extracting soil for mud bricks over many years he had brought it down to the level of the road.

Flat earth roofs survive on four houses at Mandres. Based on observation of the roofs and discussion with Mr Petros and others, we can similarly give a generalized account (Ireland et al. 2013, 264-5). Trimmed pine branches about $14 \mathrm{~cm}$ in diameter bridged the wall tops. On them were placed smaller branches of olives and shrubs; then a thick mat of thorny burnet (Sarcopoterium spinosum). On this was 
a $20 \mathrm{~cm}$-thick layer of normal earth, and lastly a very specific whitish clay called konnos. This was compressed with a stone roller some $80 \mathrm{~cm}$ long and $30 \mathrm{~cm}$ in diameter, often parked on the roof itself. Informants were very emphatic about the waterproof properties of konnos, including Mr Petros: 'When it rained this clay melted and spread and became like tar, nothing leaked through, understand?' The konnos has an active, autonomous role, also reported in the eighteenth century by the Italian traveller Giovanni Mariti: roofs were sealed with 'earth mixed with clay, which during the winter rains plugs up the fissures caused by the summer heat'. However, he notes, 'if the rains are long and continuous the inmates are obliged to make frequent repairs' (Mariti 1909, 30). Our informants were very particular about where konnos could be found, including c. $3 \mathrm{~km}$ north of Mandres, where locality names include Konnos, Konno Lakxiaes [Hollows of konnos] and Konno Tepesi [Hill of konnos] (Fig. 6).

Clearly a mud brick is far more than a humanconstructed machine. It is a convivial assemblage, a set of properties, relationships and practices that keeps on transforming itself. It has the power to deter rain, control temperature, deaden sound and provide homes for insects, birds and people. It can bring particular collaborators into dependent relationships, such as people like Mr Petros, who must work with spades, rollers and huge effort and energy to serve the soil, the mud bricks, the plaster, the konnos, the house. Like a crow demanding food from a picnicker, or wheat stalks domesticating early farmers, the soil recruits us to work on its continuing maintenance and transformation.

There is an ongoing process here: the conviviality of the mud brick persists both before and after its manufacture. Clays, organic matter, soil fauna, phosphorus, livestock and Pleistocene transportation conspire to produce the soil. Wooden forms, barrows, spades, builders, threshing sledges, straw, sherds, stones and bones work on its transformation into the shape of a $45 \times 35 \times 5 \mathrm{~cm}$ mud brick. All those inclusions, the soil chemistry and annual repairs by clay and humans maintain it in its structural role. And rain, wind, burrowing animals and collapsing roofs transform it back into soil. Elsewhere in the Survey Area we recognized imported soils as in fact decayed mud brick (Boutin et al. 2013, 113), and across the Middle East such decayed mud brick builds monumental and often nutrient-rich tells, until it is recycled as fertilizer and once again joins the soil (Quickel \& Williams 2016).

What this makes clear is that the mud brick is just one step in a longer, continuous chain of cycling and recycling, carried out by a complex and shifting network of collaborators. From Pleistocene sediment and oxide-red soil to house and melted mud brick and back to the sediment, this is the 'matter-flow' that constitutes the liveliness of the world beyond narrow physiological definitions of life (Ingold 2012, 432). Within the soil, this is carried out through the lifegiving nutrient cycles, particularly those of nitrogen and carbon. The many participants in the house continually transform themselves through the seasonality of rainfall and temperature, through human repairs in the spring and the house martins shaping their own homes of globular mud bricks in the eaves. Conviviality is enacted through these generative flows.

We humans can often come to a partial recognition of these convivial cycles and incorporate them into the myths and practices that constitute our being in the world. Across Mandres and other villages like it, the soil explicitly generates, maintains and recycles life, in the form of homes, hearths, mangers and bread ovens all built of mud brick. Living in the soil is a symbiosis that brings warmth, nutrition and shelter. The same muted recognition is clear in Mr Petros' account of making mud bricks, for all his builder's focus on the practicalities of mixing, kneading and drying. It requires collaborating with all the essential partners, not just soil, but water, straw, wood, tools, the sun and wind, horses. In the Greek Orthodox church and far beyond, bread is another powerful expression of convivial life: and like bread dough, the soil must be harvested, wettened, mixed, kneaded and baked in the sun, in a sensory process involving hands, backs and bare feet. Most of all, conviviality requires effort. It is 'hard work, very tiring'. Listen: it needs close attention and engagement. Understand?

\section{Soil, conviviality and landscape}

To treat soil, or any other environmental agent, as a human-made and human-operated machine does a gross injustice to the astonishing conviviality of its multifarious partners. It grows and transforms itself quite independently of any human agency, and with infinitely more live-giving effect. But we are blinded by the walls of human exceptionalism that we have constructed round ourselves (Tsing 2012, 144). We try to separate ourselves from our environment, to distinguish organism, ecosystem and environment, to divide ourselves somehow bodily from earthly materialities (Ingold 2012, 438; Whatmore \& Hinchcliffe 2010, 448). The impact of this separation is that our imposition on the soil and other environmental players transgresses the limits of conviviality, resulting in the suppression of the lively interaction that sustains us all. 
Even landscape archaeology has suffered from this disengagement of humans from their essential non-human partners. Treating soil as a proxy for human productivity is denying the conviviality of a lively and healthy landscape-and is unable to understand the symptoms of an ailing one. To embrace interaction, partnership and interdependency requires a new, convivial ecology of practices (Paulson 2001, 111-12). Archaeological landscape and survey projects need not just geomorphologists, but soil scientists, in particular ones willing to engage with the active and lively relationships and symbioses with a staggering range of partners, non-human and human alike. For any specific place the project is investigating, how have the soil and the human community worked together? How convivial was that collaboration? What other players took part-draught animals, climate change, taxation regimes, underlying geology, wild fires, fences, past histories of alluviation?

More widely, projects need to study their particular places with a wide range of disciplinary specialists, who will walk and talk through the different players, roles, connections, dependencies, symbioses, tensions, co-productions and assemblagesboth the ones which tend to increase conviviality and those which reduce it. Engaging with all of these approaches and perspectives requires the willingness to cross disciplinary boundaries into difficult zones, and to enact the conviviality ourselves through professional collaboration (Hitchings 2003, 102; McNeill \& Winiwarter 2006, 4). This also means that theoretical archaeology needs the sciences. Assemblage theory, symmetrical archaeology and actor-network theory can all claim to incorporate non-humans into their interpretations of the world, but to achieve that their practitioners need to engage with the relevant sciences as much as with philosophy and social theory.

All this requires not so much changed disciplinary practices or recording techniques, but the transformation of communication between the disciplines. When specialists share their understandings of the 'intermediate objects' that link their researchsoils, rivers, mud bricks, structures-they begin to treat them as actors in themselves (Buller 2009, 398). These soils, rivers and mud bricks join with the specialists in the construction of new, shared assemblages of knowledge, as well as working with a host of partners in the ongoing, emergent life of the landscape. This article, with the long interdisciplinary sharing of fieldwork with colleagues that underlies it, is an attempt to construct such a convivial assemblage of knowledge.

It is not just archaeologists who need to engage with soils. Because of our increasing entrapment by the 'things' we make, rely on and have to keep on fixing, argues Ian Hodder, we need to 'change what it is to be human' (Hodder 2014, 34). When we look at human 'fixing' of the soil, the drastic curtailment of its convivial capacities, he is clearly right. It has been industrialized through monoculture, pesticides, weed-killers and excessive fertilization. What were once semi-permeable interfaces have now been hard-capped. It suffers ongoing degradation through ploughing across the contours, short-sighted flood defences, and of course all the impacts of anthropogenic climate change.

By re-engaging with the soil and rebuilding our role in its ongoing cycles, we can join in the conviviality once again. Numerous studies, for example, have shown the symbiotic benefits to all soil partners (including people) of convivial practices such as smallscale cultivation in urban gardens and allotments (Edmondson et al. 2014). Soils are even a potentially huge carbon sink to draw down excess carbon dioxide from the atmosphere (Hillel 2008, 233-46).

As human co-beings, our biggest challenge is to allow ourselves to be affected by the soil and its partners (Whatmore \& Hinchcliffe 2010, 446). We need to cultivate a 'patient sensory attentiveness' (Bennett 2010, xiv), or just, to build on what Mr Petros tells us, to 'listen'. This involves both an ethical intention towards the soil and a changed set of practices (Fouke 2011, 153-8; Minami 2009, 611-14). There are times, too, when we need to sit in front of the sheer mindboggling conviviality of soil in awe and astonishment, rather than reducing it to a tidy analysis or a humanized Other (Pétursdóttir 2012, 599-600; Witmore 2014, 219-23). Evocation of our relationships with the soil through art, prose, poetry and performance can be a powerful partner to the scientific analysis of chemistry, structure and sociological data. In a convivial landscape, we humans think with soil, and the soil thinks with fungal networks, microbial action, symbiotic relationships, ion exchange-and us.

\section{Acknowledgements}

I am very grateful to all the disciplinary and interdisciplinary specialists, team members, supporters and funders of the Troodos Archaeological and Environmental Survey Project, particularly the Arts and Humanities Research Council (Grant no. RG/4164/14633), the Department of Antiquities of the Republic of Cyprus and Ian Evans, Erin Gibson and Tracy Ireland. I have learnt an enormous amount from the local people we interviewed, and am particularly grateful to Michalis Christodoulou Ppandjiaris, and to Marios Hadjianastasis for his interviewing and translation. I am very grateful to Neil Erskine, Laurence Ferland, Erin Gibson, Kevin Kay, Colin Robins and three 
anonymous reviewers for their very helpful and perceptive comments on earlier drafts. And huge thanks to Jay Noller for walking, talking and conviviality of all kinds.

Michael Given
School of Humanities
University of Glasgow
Glasgow G12 8QQ
UK
Email: Michael.Given@glasgow.ac.uk

\section{References}

Ashkenazi, E., Y. Avni \& G. Avni, 2012. A comprehensive characterization of ancient desert agricultural systems in the Negev Highlands of Israel. Journal of Arid Environments 86, 55-64.

Ashman, M.R. \& G. Puri, 2002. Essential Soil Science: A clear and concise introduction to soil science. Oxford: Blackwell Science.

Babikova, Z., L. Gilbert, T.J.A. Bruce, et al., 2013. Underground signals carried through common mycelial networks warn neighbouring plants of aphid attack. Ecology Letters 16(7), 835-43.

Barrett, J.C., 2014. The material constitution of humanness. Archaeological Dialogues 21(1), 65-74.

Bassey, M., 2012. Convivial Policies for the Inevitable: Global warming, peak oil, economic chaos. Brighton: Book Guild.

Bennett, J., 2010. Vibrant Matter: A political ecology of things. Durham (NC): Duke University Press.

Blume, H.-P. \& P. Leinweber, 2004. Plaggen soils: landscape history, properties, and classification. Journal of Plant Nutrition and Soil Science 167(3), 319-27.

Boutin, A., M. Given, I. Banks, et al., 2013. The Karkotis valley, in Landscape and Interaction: The Troodos Archaeological and Environmental Survey Project, Cyprus. Volume 2: The TAESP landscape, eds. M. Given, A.B. Knapp, L. Sollars, J.S. Noller \& V. Kassianidou. London: Council for British Research in the Levant, 51-151.

Buller, H., 2009. The lively process of interdisciplinarity. Area 41(4), 395-403.

Bunn, S., 2014. Making plants and growing baskets, in Making and Growing: Anthropological studies of organisms and artefacts, eds. E. Hallam \& T. Ingold. Farnham: Ashgate, 163-81.

Christodoulou, D., 1959. The Evolution of the Rural Land Use Pattern in Cyprus. Bude: Geographical Publications.

Crellin, R.J., 2017. Changing assemblages: vibrant matter in burial assemblages. Cambridge Archaeological Journal 27(1), 111-25.

Delipetrou, P., J. Makhzoumi, P. Dimopoulos \& K. Georghiou, 2008. Cyprus, in Mediterranean Island Landscapes: Natural and cultural approaches, eds. I.N. Vogiatzakis, G. Pungetti \& A.M. Mannion. (Landscape Series 9.) Berlin: Springer, 170-203.
Edmondson, J.L., Z.G. Davies, K.J. Gaston \& J.R. Leake, 2014. Urban cultivation in allotments maintains soil qualities adversely affected by conventional agriculture. Journal of Applied Ecology 51(4), 880-89.

Evans, J.G., 2003. Environmental Archaeology and the Social Order. London: Routledge.

Forbes, H., 2007. Meaning and Identity in a Greek Landscape: An archaeological ethnography. Cambridge: Cambridge University Press.

Forbes, H., 2013. Off-site scatters and the manuring hypothesis in Greek survey archaeology: an ethnographic approach. Hesperia 82, 551-94.

Fouke, D.C., 2011. Humans and the soil. Environmental Ethics 33, 147-61.

Given, M., 2004. From density counts to ideational landscapes: intensive survey, phenomenology and the Sydney Cyprus Survey Project, in Mediterranean Archaeological Landscapes: Current issues, eds. E. Athanasopoullou \& L. Wandsnider. Philadelphia (PA): University of Pennsylvania Museum of Archaeology and Anthropology, 165-82.

Given, M., A.B. Knapp, J.S. Noller, L. Sollars \& V. Kassianidou (eds.), 2013a. Landscape and Interaction: The Troodos Archaeological and Environmental Survey Project, Cyprus. Volume 1: Methodology, analysis and interpretation. London: Council for British Research in the Levant.

Given, M., J. Noller \& L. Wells, 2003. SCY114: Mitsero Lambadhiotissa: check dams and Byzantine church, in The Sydney Cyprus Survey Project: Social approaches to regional archaeological survey, eds. M. Given \& A.B. Knapp. Los Angeles (CA): UCLA Cotsen Institute of Archaeology, 187-92.

Given, M., L. Sollars, A. Boutin, et al., 2013b. The plains, in Landscape and Interaction: The Troodos Archaeological and Environmental Survey Project, Cyprus. Volume 2: The TAESP landscape, eds. M. Given, A.B. Knapp, L. Sollars, J.S. Noller \& V. Kassianidou. London: Council for British Research in the Levant, 6-50.

Hadjinicolaou, P., C. Giannakopoulos, C. Zerefos, M.A. Lange, S. Pashiardis \& J. Lelieveld, 2011. Mid-21st century climate and weather extremes in Cyprus as projected by six regional climate models. Regional Environmental Change 11(3), 441-57.

Hamilakis, Y., 2017. Sensorial assemblages: affect, memory and temporality in assemblage thinking. Cambridge Archaeological Journal 27(1), 169-82.

Hamilakis, Y. \& A.M. Jones, 2017. Archaeology and assemblage. Cambridge Archaeological Journal 27(1), 7784.

Hillel, D., 2008. Soil in the Environment. Burlington (MA): Academic Press.

Hitchings, R., 2003. People, plants and performance: on actor network theory and the material pleasures of the private garden. Social \& Cultural Geography 4(1), 99114.

Hodder, I., 2012. Entangled: An archaeology of the relationships between humans and things. Malden (MA): WileyBlackwell. 
Hodder, I., 2014. The entanglement of humans and things: a long-term view. New Literary History 45, 19-36.

Illich, I., 1975. Tools for Conviviality. Glasgow: Fontana/ Collins.

Ingold, T., 2007. Materials against materiality. Archaeological Dialogues 14, 1-16.

Ingold, T., 2012. Towards an ecology of materials. Annual Review of Anthropology 41, 427-42.

Ingold, T. \& E. Hallam, 2014. Making and growing: an introduction, in Making and Growing: Anthropological studies of organisms and artefacts, eds. E. Hallam \& T. Ingold. Farnham: Ashgate, 1-24.

Ionas, I., 1988. La maison rurale de Chypre (XVIIIe-XXe siècle): aspects et techniques de construction [The rural house in Cyprus (18th-20th century): features and construction techniques]. Nicosia: Cyprus Research Centre.

Ionas, I., 2001. Paradhosiaka epangelmata tis Kyprou [Traditional occupations of Cyprus]. Nicosia: Cyprus Research Centre.

Ireland, T., I. Evans, E. Moutafov \& C. Schriwer, 2013. Architecture in the landscape, in Landscape and Interaction: The Troodos Archaeological and Environmental Survey Project, Cyprus. Volume 1: Methodology, analysis and interpretation, eds. M. Given, A.B. Knapp, J.S. Noller, L. Sollars \& V. Kassianidou. London: Council for British Research in the Levant, 261-77.

Jones, A.M. \& N. Boivin, 2010. The malice of inanimate objects: material agency, in The Oxford Handbook of Material Culture Studies, eds. D. Hicks \& M.C. Beaudry. Oxford: Oxford University Press, 333-51.

Jones, R., 2009. Manure and the medieval social order, in Land and People: Papers in memory of John G. Evans, eds. M.J. Allen, N. Sharples \& T. O'Connor. Oxford: Prehistoric Society/Oxbow, 215-25.

Knappett, C., 2012. Materiality, in Archaeological Theory Today, ed. I. Hodder. Cambridge: Polity, 188-207.

Lelieveld, J., P. Hadjinicolaou, E. Kostopoulou, et al., 2012. Climate change and impacts in the eastern Mediterranean and the Middle East. Climatic Change 114(3-4), 667-87.

Macfarlane, R., 2015. Landmarks. London: Hamish Hamilton.

Main, C.E., A.H.F. Robertson \& R.N. Palamakumbura, 2016. Pleistocene geomorphological and sedimentary development of the Akaki River catchment (northeastern Troodos Massif) in relation to tectonic uplift versus climatic change. International Journal of Earth Sciences 105(1), 463-85.

Mariti, G., 1909. Travels in the Island of Cyprus. Cambridge: Cambridge University Press.

McCormick, M., U. Buntgen, M.A. Cane, et al., 2012. Climate change during and after the Roman Empire: reconstructing the past from scientific and historical evidence. Journal of Interdisciplinary History 43(2), 169220.

McMaster, T. \& D. Wastell, 2005. The agency of hybrids: overcoming the symmetrophobic block. Scandinavian Journal of Information Systems 17, 175-82.
McNeill, J.R. \& V. Winiwarter, 2006. Soils, soil knowledge and environmental history: an introduction, in Soils and Societies: Perspectives from environmental history, eds. J.R. McNeill \& V. Winiwarter. Strond, Isle of Harris: White Horse Press, 1-6.

Minami, K., 2009. Soil and humanity: culture, civilization, livelihood and health. Soil Science \& Plant Nutrition 55(5), 603-15.

Montgomery, D.R., 2007. Soil erosion and agricultural sustainability. Proceedings of the National Academy of Sciences 104(33), 13268-72.

Nativ, A., 2014. Anthropocentricity and the archaeological record: towards a sociology of things. Norwegian Archaeological Review 47(2), 180-95.

Noller, J. \& N. Urwin, 2013. The environmental record of the TAESP landscape, in Landscape and Interaction: The Troodos Archaeological and Environmental Survey Project, Cyprus. Volume 1: Methodology, analysis and interpretation, eds. M. Given, A.B. Knapp, J.S. Noller, L. Sollars \& V. Kassianidou. London: Council for British Research in the Levant, 296-320.

Olsen, B., 2012. Symmetrical archaeology, in Archaeological Theory Today, ed. I. Hodder. Cambridge: Polity, 20828.

Panaretos, A., 1967. Kipriaki Yeoryiki Laografia [Cypriot agricultural folklore]. Nicosia: Sinergatiki Kendriki Trapeza.

Paulson, W., 2001. For a cosmopolitical philology: lessons from Science Studies. SubStance 30(3), 101-19.

Pétursdóttir, P., 2012. Small things forgotten now included, or what else do things deserve? International Journal of Historical Archaeology 16(3), 577-603.

Pimentel, D., 2006. Soil erosion: a food and environmental threat. Environment, Development and Sustainability 8, 119-37.

Quickel, A.T. \& G. Williams, 2016. In search of sibākh: digging up Egypt from antiquity to the present day. Journal of Islamic Archaeology 3, 98-108.

Rickson, R.J., L.K. Deeks, A. Graves, J.A.H. Harris, M.G. Kibblewhite \& R. Sakrabani, 2015. Input constraints to food production: the impact of soil degradation. Food Security 7(2), 351-64.

Salisbury, R.B., 2012a. Engaging with soil, past and present. Journal of Material Culture 17(1), 23-41.

Salisbury, R.B., 2012b. Soilscapes and settlements: remote mapping of activity areas in unexcavated prehistoric farmsteads. Antiquity 86, 178-90.

Strang, V., 2014. Fluid consistencies. Material relationality in human engagements with water. Archaeological Dialogues 21, 133-50.

Tsing, A., 2010. Arts of inclusion, or how to love a mushroom. Manoa 22(2), 191-203.

Tsing, A., 2012. Unruly edges: mushrooms as companion species. Environmental Humanities 1, 141-54.

van der Veen, M., 2014. The materiality of plants: plantpeople entanglements. World Archaeology 46, 799-812.

Vita-Finzi, C., 1969. The Mediterranean Valleys: Geological changes in historical times. Cambridge: Cambridge University Press. 
Wells, E.C., 2006. Cultural soilscapes, in Function of Soils for Human Societies and the Environment, eds. E. Frossard, W.E.H. Blum \& B.P. Warkentin. London: Geological Society, $125-32$.

Whatmore, S.J. \& S. Hinchcliffe, 2010. Ecological landscapes, in The Oxford Handbook of Material Culture Studies, eds. D. Hicks \& M.C. Beaudry. Oxford: Oxford University Press, 440-58.

Wilkinson, T.J., 2003. Archaeological Landscapes of the Near East. Tucson (AZ): University of Arizona Press.

Witmore, C.L., 2014. Archaeology and the new materialisms. Journal of Contemporary Archaeology 1(2), 203 46.

Wylie, J., 2007. Landscape. London: Routledge.

Yiangoullis, K.G., 1992. Epitomo etymoloyiko kai ermineftiko lexiko tis Kypriakis dhialektou [Short etymological and interpretive dictionary of the Cypriot dialect]. Nicosia: K.G. Yiangoullis.
Zomeni, Z. \& A. Bruggeman, 2013. Soil resources of Cyprus, in Soil Resources of Mediterranean and Caucasus Countries: Extension of the European Soil Database, eds. Y. Yigini, P. Panagos \& L. Montanarella. Luxembourg: Joint Research Centre of the European Commission, 37-59.

\section{Author biography}

Michael Given is Senior Lecturer in Archaeology in the School of Humanities, University of Glasgow. His research interests include archaeological survey and landscape archaeology, the historical periods in the Eastern Mediterranean and the relationship between people and the environment. Between 2002 and 2012 he was co-director of the Troodos Archaeological and Environmental Survey Project in Cyprus. 